\title{
THE ACHIEVEMENTS OF THE LUBLIN SCHOOL OF FUNDAMENTAL THEOLOGY IN THE FIELD OF ECCLESIOLOGY
}

\begin{abstract}
Academic research in the field of ecclesiology has been conducted at John Paul II Catholic University of Lublin (CUL) from the beginning of its existence, among others, in the Department of Fundamental Theology headed in 1918 by Rev. Piotr Kremer. Research intensified after the creation of the second Department of Fundamental Theology_Ecclesiology (on June 23 , 1958), which in the years 1964-91 was headed by Rev. Stanisław Nagy (Cardinal since 2003). Along with this, the Lublin School of Fundamental Theology developed, whose most prominent contributor was Rev. Marian Rusecki. The aim of this article is to present the achievements of the Lublin center (authors, works, research problems, its development) in the field of ecclesiology. The article will not repeat the contents of other articles included in this volume $^{1}$ but will be composed of the following sections: (1) the ecclesiological contents before the establishment of the Lublin School of Fundamental Theology, (2) the ecclesiological contents in the works of Rev. Edward Kopeć, (3) the ecclesiological achievements of Rev. Stanisław Nagy and his students, (4) the ecclesiological achievements of Rev. Marian Rusecki and his students, and (5) a conclusion.
\end{abstract}

Keywords: apologetical ecclesiology; Catholic Church; Catholic ecclesiology; Church of Christ; credibility of the Church; demonstratio catholica; ecclesiological fact; ecclesiology; fundamental ecclesiology; fundamental theology; Lublin School of Fundamental Theology; credibility of the Church.

\section{ECCLESIOLOGICAL CONTENTS BEFORE THE LUBLIN SCHOOL OF FUNDAMENTAL THEOLOGY}

Rev. Piotr Kremer (1878-1951) was the first director of the Department of Fundamental Theology at the Catholic University of Lublin. He was in

Rev. Krzysztof Kaucha, CUL Prof. - Chair of Christology and Fundamental Ecclesiology at the CUL Institute of Fundamental Theology, address: ul. Nałęczowska 94, 20-831 Lublin; e-mail: kkaucha@CUL.pl

${ }^{1}$ Especially those written by Rev. Jacenty Mastej, Rev. Marek Żmudziński, Rev. Paweł Borto and Rev. Krzysztof Kaucha. 
favor of the neo-scholastic concept, undertaking topics at the meeting point between science and faith in the context of neo-positivism and materialism, the issue of theological cognition and sources of theology, as well as ecclesiology, in which he studied the history of ecclesiology, the ecclesiology of Vatican I, and practiced comparative theology on Catholicism and Russian Orthodoxy, which he knew due to his work at the Academic Seminary in St. Petersburg. ${ }^{2}$

He has published several research articles, follow-ups and more than 20 reviews. He led, among others, the following lectures and seminars: "The Church as an Institution of Power," "The Idea of the Church among the Apostolic Fathers" (in the academic year 1918/19), "The Primacy of St. Peter in the light of the New Testament Books," "The Apologetic Value of the Four Attributes Theory" (1919/20), "Catholic Teaching about the Church during the Enlightenment of Orthodox Theologians," "The Critical Partition and Major Charges in Orthodox Theology against the Papacy" (1920/21), "The Church, Guardian and Teacher of the Revealed Word" (1928/29), "On the Infallibility of the Magisterium" (1929/30). ${ }^{3}$

Under his supervision, in the period between 1918-39, there were 4 doctoral dissertations, including 3 on ecclesiology: Rev. Michał Krzywicki's "Papal Primacy and the Eastern Churches in the Period of Nestorianism," Rev. Henryk Hlebowicz's "The Teaching on the Unity of the Church in St. John Chrysostom," Rev. Marcin Wojciechowski's "The Infallibility of the Church of Christ according to A.S. Chomiakow and his Supporters." ${ }^{4}$ His legacy, including documents, correspondence, lecture notes and minutes from the faculty council meetings were found by Rev. K. Kaucha in the Archives of the Kraków Province of the Order of Discalced Carmelites in Kraków and donated by the Order to the Institute of Fundamental Theology (IFT) on April 22, 2016. Its initial cataloging was done by Dr. Irena Wodzianowska from the Institute of History at the Catholic University of Lublin.

\footnotetext{
${ }^{2}$ Marian RuSECKI, "Kremer Piotr," in Leksykon Teologii Fundamentalnej, ed. Marian Rusecki, Krzysztof Kaucha, Ireneusz S. Ledwoń, Jacenty Mastej (Lublin-Kraków: Wydawnictwo M, 2002), 690-691.

${ }^{3}$ Romuald ŁUKASZYK, "Pięćdziesięciolecie teologii fundamentalnej na KUL (1919-1968)," Roczniki Teologiczno-Kanoniczne 15, no 2 (1968): 5-53.

${ }^{4}$ Romuald ŁUKASZYK, "Pięćdziesięciolecie teologii fundamentalnej na KUL (1919-1968)," 13, 41-42. The fourth dissertation by Rev. Stanisław Cieślik entitled "Siła dowodowa cudu" ["Evidence of Miracles"] was lost during the war. In the period 1918-39, four doctorates were written for fundamental theology, all lead by Rev. Kremer.
} 
Following Rev. Kremer's work, ecclesiology was taught by Father doc. (habilitated assistant professor) Bogusław Waczyński SI (1907-81). ${ }^{5} \mathrm{He}$ obtained a doctorate in comparative theology in Rome at the Pontifical Oriental Institute, where he studied in 1934-37, written on the basis of the dissertation "On Papal Primacy in the Polemical Literature in the Period of the Union of Brest in 1577-1612." In his lectures, in addition to comparative issues, he addressed the issue of the primacy of the Bishop of Rome. The Ministry of Higher Education forbade him to lecture at CUL in 1951-56. His achievements include over 40 works. He published three chapters in Catholic Dogmatics by Rev. W. Granat, including an ecclesiological work titled "Teachings about the Church according to newer non-Catholic Eastern Theologians." 6 Under his supervision, Rev. Tomasz Bielski wrote his doctoral dissertation, "The Ecclesiology of Włodzimierz Siergiejewicz Sołowiew." During the occupation, he saved Jews. He was entered on the list of the Ulma Family Museum of Righteous Poles Saving Jews During World War II in Markowa. ${ }^{7}$

\section{ECCLESIOLOGICAL CONTENTS IN THE WORK BY REV. EDWARD KOPEĆ AND HIS STUDENTS}

Rev. Edward Kopeć, who pioneered the Lublin School of Fundamental Theology, taught ecclesiological and apologetic issues for a short time before these lectures were taken over by Rev. Stanisław Nagy. From that moment on, Rev. Kopeć only dealt with Christological facts. He included ecclesiological contents in scripts for students, and these had many editions. In subsequent editions, we can see the gradual broadening of the scope of ecclesiological subjects. Rev. Kopeć understood apologetic ecclesiology to be an ecclesiological fact showing the truth of the Church's origins in Christ (he was innovative in writing that the entire life of Jesus was the initiation of the Church $)^{8}$ and the truthfulness of its essential structural elements were

\footnotetext{
${ }^{5}$ ŁUKASZYK, "Pięćdziesięciolecie teologii fundamentalnej na KUL (1919-1968)," 17-18, 47.

${ }^{6}$ Wincenty Granat, Dogmatyka katolicka, vol. 4 (Lublin, 1960), 234-240. Cf. ŁuKASZYK, "Pięćdziesięciolecie teologii fundamentalnej na KUL (1919-1968)," 18.

${ }^{7} \mathrm{http}: / /$ muzeumulmow.pl/pl/_(accessed: 11.02. 2018).

8 "The rise of the Church should be understood not in the sense of a single act, but in the sense of a long-term process." Edward Kopeć, Teologia fundamentalna, new expanded and improved edition (Lublin: RW KUL, 1976³), 180.
} 
understood as external-organizational (primacy, apostolate, succession, power, authority, the Magisterium of the Church and its infallibility).

Rev. Kopeć also took into account the so-called marks of the Church (notae Ecclesiae), describing them as a way of proving the truth about the Catholic Church and the inaccuracy of other Churches. ${ }^{9}$ Two PhDs in ecclesiology were written under his guidance, namely Rev. Stefan Januszewicz's "The Structure of the Highest Authority of the Church in the Conciliarist-Basilian Treaties of the Masters of the University of Kraków"10 and Rev. Romuald Łukaszyk's “Justification of the Church's Authority Structure in the light of Research on Tradition in Modern (Catholic and Protestant) theology." Rev. Kopeć's influence on the Lublin school of ecclesiology was more indirect. His research on Christian Revelation, testimonies of the resurrection of Jesus Christ, its concepts and reasons for credibility, his study on miracles as a faith motivation and his recognition consequently lead to giving the Church credibility as well.

\section{THE ECCLESIOLOGICAL HERITAGE OF REV. STANISEAW NAGY ${ }^{11}$ AND HIS STUDENTS}

Rev. Stanisław Nagy (1921-2013) finished PhD studies in fundamental theology at CUL (1950-52) and defended his doctoral degree in 1954 based on the dissertation "The Office of Teaching in the Early Church" written under the direction of Rev. Prof. B. Radomski. Its subject was responsibility for the truth and the organizational structure of the post-apostolic Church. Its explanation of the beginning and evolution of the terminology related to the ecclesiastical hierarchy in this period is original: episkopoi, presbyteroi and diakonoi. The thesis justifies the priority of teaching from among the other tasks of the successors of the Apostles. ${ }^{12}$

He began his academic work at CUL in 1958 in the II Chair of Fundamental Theology and Ecclesiology. He completed his habilitation based on

\footnotetext{
${ }^{9} \mathrm{He}$ concluded with the following: "Therefore, proving through signs shows that the true Church of Christ is the Catholic Church" (ibid., 234).

${ }^{10}$ ŁUKASZYK, "Pięćdziesięciolecie teologii fundamentalnej na KUL (1919-1968)," 50-51. The reviewers were Rev. Wincenty Kwiatkowski and Rev. Bolesław Kumor.

${ }^{11}$ This section will omit the contents found in Rev. Marek Żmudziński’s article.

${ }^{12}$ Stanisław NAGY, "Sekcja Teologii Fundamentalnej," in Księga pamiątkowa w 75-lecie Katolickiego Uniwersytetu Lubelskiego. Wktad w kulturę polska w latach 1968-1993, ed. Marian Rusecki (Lublin: RW KUL, 1994), 191.
} 
his research and the dissertation "Via notarum in Contemporary Apologetic Ecclesiology," which he completed in 1968. In later publications, he dealt with the ecclesiology of Vatican II, especially the Church's collegiality, membership in it, its truthfulness, the theology of the local Church and the role of lay people. He held many positions in foreign bodies, was a member of the International Theological Commission in 1986-97, the environment of theologians in Poland and at the Catholic University of Lublin (curator of the Academic Circle of Theologians and the initiator of Ecclesiological Weeks). In 2003, John Paul II granted him the dignity of a cardinal.

The object of his academic research was ecclesiology, first apologetics (or fundamental theology, terms he often used interchangeably), and over time, ecumenism and the pontificate of John Paul II. His achievements include over 250 works (five books, numerous research articles, popular academic works, journalism and encyclopedia entries). Under his direction, 14 doctoral dissertations were created.

There is an evolution in his thinking. According to Rev. Rusecki, this refers to the subject of the faultless transmission of Christ's Revelation (initially, Rev. Nagy considered this to be the Magisterium, the teaching ministry of the Church, but later it including the whole Church), on the concept of the Church (initially, following R. Bellarmine, he exposed institutional and structural elements, and over time, the mystery and its two-dimensions, meaning the Church having supernatural and human dimensions), the origins of the Church (initially he wrote about its being established on primacy, apostolate and their succession; over time, he perceived the whole life of Jesus as an ecclesiogenesis), the interpretation of primacy and apostolate (initially he understood them in the spirit of juridical ecclesiology, yet over time, he deepened the theological reflection exposing the Church's diaconate, witness and love in ecclesiastical authority), methods in apologetic ecclesiology (first he advocated the historical method, primacy, yet over time he included the methods of signs, ecclesiology and analysis, also called empirical or phenomenological, consisting of several stages: selecting the current Church's distinguishing phenomena by directly looking at it, analyzing their origins in confrontation with historical and socio-psychological laws, stating the supernatural element of the Church, which cannot be explained in a natural way, and the conclusions on the founder's transcendence; this 
method has strong sides and weaknesses), ${ }^{13}$ using arguments based on characteristics (initially understanding them quite statically as a permanent endowment of the Church, almost a stigmata, while only later he began to understand their character and dynamics as a task for the Church whose fulfillment can only materialize at the Eschaton), gradually incorporating an ecumenical perspective (at first it can be seen as exclusivist due to the view that only the Roman Catholic Church is the true Church of Christ, but later he turned to ecclesiological inclusivity, seeing the presence of this Church in non-Catholic communities; he always expressed that the Roman Catholic Church is the fullness of ecclesial elements coming from Jesus Christ). ${ }^{14}$

Among Rev. Nagy's colleagues, Rev. Dr. hab. Romuald Łukaszyk (193081) was the most important. In 1959, he began his specialist studies at the Section of Fundamental Theology of the Catholic University of Lublin. In 1965, he obtained a bachelor's degree on the basis of the work "The Teaching of the Church as the Motive of the Credibility in the First Vatican Council's Proclamation." In 1964, he began his academic and didactic work in the section, and in 1966, he defended his doctoral dissertation entitled "Rationale for the Church's Structure of Authority in the Light of Research on Tradition in Contemporary Theology (Catholic and Protestant)." Its reviewers (Rev. W. Kwiatkowski and Rev. W. Granat) appreciated its high degree of difficulty, extensive research material, innovation and ecumenical side opening the way to ecumenical theology. Rev. Łukaszyk lectured, among others, on ecclesiology, which included ecumenical issues.

Since 1969, he was delegated to work in the Catholic Encyclopedia, and in 1970 he was the head of the Inter-Faculty Department of Lexicography of the Catholic University of Lublin. The term "Father of the Catholic Encyclopedia" clung to him. In 1975, he obtained a habilitation based on his academic achievements. He published 16 treatises and research articles, 10 reports and discussions on theological and fundamental literature, 11 reviews and 73 encyclopedia entries (including many from fundamental theology). His research in the field of ecclesiology first dealt with the position of Vatican I (the

\footnotetext{
${ }^{13}$ Marian RUSECKI, Wiarygodność chrześcijaństwa, vol. 1: Z teorii teologii fundamentalnej, (Lublin: TN KUL, 1994), 315-321.

${ }^{14}$ Zbigniew KRZYSZOwSKI, "Nagy Stanisław," in Leksykon Teologii Fundamentalnej, 826-827; Adam KuMOREK, "Wiarygodność chrześcijaństwa w pismach kardynała Stanisława Nagyego SCJ" (Warsaw, 2013; doctoral dissertation); ŁUKASZYK, "Pięćdziesięciolecie teologii fundamentalnej na KUL (1919-1968)", 22-24; Stanisław NAGY, "Sekcja Teologii Fundamentalnej," Roczniki Teologiczne 43, no 2 (1996): 191-193 (volume dedicated to Rev. S. Nagy).
} 
constitution De fide catholica) towards ecclesiological methods (historical and empirical), then with contemporary ecclesiology but before Vatican II, and later with the ecclesiology of Vatican II. Even before this council, he emphasized, on the basis of literature, the theological concept of the Church as a historical and pedagogical community and the two-dimensions of the Church analogous to the dual nature of Jesus Christ. He also applied these thoughts to the Church's structure and authority. Examining the teaching of the last Council on belonging to the Church, he concluded that "theologically, there is one form of belonging, and historically it is realized through a full incarnation, a relationship with the Church and belonging to the People of God." 15 The academic thoughts of Rev. Łukaszyk can be summed up saying that he started with the personalistic concept of the faith, whose subject is the entire man as a person, and then attempted to apply this to ecclesiology, which he did independently and in a novel way. His personal library, numbering 1,211 written works mostly in foreign languages, is found in the reading room of CUL's Theology Department.

Other students and co-workors of Rev. Nagy included: Rev. Dr. Jerzy Borowiec, Father Dr. Tomasz Ludwisiak SI, Rev. Mieczysław Piwowarek SCI, Rev. Prof. Dr. hab. Henryk Seweryniak and Rev. Dr. Zbigniew Krzyszowski.

Rev. Jerzy Borowiec (born 1949) was an employee of the Second Chair of Fundamental Theology in 1982-84. In 1984, he obtained a doctoral degree in fundamental theology on the basis of the dissertation "The Structure of the Original Church according to Hans Küng" written under the direction of Rev. Nagy. He is the author of 15 academic articles on ecclesiological issues. ${ }^{16}$

Fr. Tomasz Ludwisiak (born 1946) studied in 1978-80 at the Pontifical Gregorian University in Rome, where he obtained a bachelor's degree in fundamental theology. He was an employee of the Second Chair of Fundamental Theology in the years 1983-85. In 1985, he obtained a doctoral degree in fundamental theology on the basis of the dissertation "The Formation

\footnotetext{
${ }^{15}$ ŁUKASZYK, "Pięćdziesięciolecie teologii fundamentalnej na KUL (1919-1968)," 26-28. Cf. Marian BANASZAK, “Ksiądz Romuald Łukaszyk (1930-81)," Roczniki Teologiczne 31, no 2 (1984): 5-7; S. NAGY, "Sekcja Teologii Fundamentalnej," 193-194; Romuald NIPARKO, "Wspomnienie o księdzu Romualdzie Łukaszyku," Roczniki Teologiczne 31, no 2 (1984): 9-11; Marian RuSECKI, "Eukaszyk Romuald," in Leksykon Teologii Fundamentalnej 763-764; "Wykaz prac naukowych Ks. doc. dra hab. Romualda Łukaszyka," Roczniki Teologiczne 31, no 2 (1984): 13-17.

${ }^{16}$ Archiwum Uniwersyteckie KUL, Referat Personalny, Akta osobowe pracowników, sygn. A 1684; Archiwum Uniwersyteckie KUL, Wydział Teologii, Akta osobowe studentów, sygn. 27131; Zbigniew KRZYszowsKI, “Borowiec Jerzy,” in Leksykon Teologii Fundamentalnej, 155-156.
} 
of the Doctrine on Charisms at the Second Vatican Council and the Charismatic Renewal in the Church," promoted by Rev. S. Nagy. His academic achievements include several research articles, reviews and translations. He works at the Pontifical Faculty of Theology Bobolanum in Warsaw and he mainly publishes in Studia Bobolanum and Przeglad Powszechny. ${ }^{17}$

Rev. Mieczysław Piwowarek (born in 1952) was an employee of the Second Chair of Fundamental Theology in 1986-88. In 1980-84, he completed doctoral studies in fundamental theology at CUL, during which he obtained a bachelor's degree based on the work "The Holy Spirit and the Problem of the Founding of the Church in the Constitution Lumen Gentium" (1982), written under the direction of Rev. Nagy. ${ }^{18}$

Rev. Henryk Seweryniak (born in 1951) worked in the Second Department of Fundamental Theology in the years 1988-93. He started doctoral studies at the Department of Dogmatic Theology at the Catholic University of Lublin. He obtained his doctorate in fundamental theology in 1984 at the Gregorian based on the dissertation "Espérence et compréhension dans l'herméneutique de Paul Ricoeur," which he wrote under the direction of R. Latourelle. In 1993, he earned his habilitation degree at CUL based on his achievements and the dissertation "Anthropology and Fundamental Theology. A Study of the Fundamental Theology Anthropology of Wolfhard Pannenberg. ${ }^{19}$ Shortly after, he started working at ATK in Warsaw. ${ }^{20}$

Rev. Zbigniew Krzyszowski (born in 1954) worked in the Second Department of Fundamental Theology in the years 1992-2009. He obtained his doctorate in fundamental theology in 1992 at CUL on the basis of the dissertation "The Church's Credibility in the Teaching of John Paul II" written under the direction of Rev. Nagy. ${ }^{21}$

\footnotetext{
${ }^{17}$ Archiwum Uniwersyteckie KUL, Referat Personalny, Akta osobowe pracowników, sygn. A 1788; Archiwum Uniwersyteckie KUL, Wydział Teologii, Akta osobowe studentów, sygn. 028962.

${ }_{18}^{18}$ Archiwum Uniwersyteckie KUL, Referat Personalny, Akta osobowe pracowników, sygn. A 1976; Archiwum Uniwersyteckie KUL, Wydział Teologii, Akta osobowe studentów, sygn. 028365.

${ }^{19}$ [Anthropology and Fundamental Theology. A Study of Fundamental Theological Anthropology by Wolfhart Pannenberg], (Płock, 1993).

${ }^{20}$ Paweł BORTO, "Seweryniak Henryk," in Leksykon Teologii Fundamentalnej, 1099-1100.

${ }^{21}$ Jacenty MASTEJ, “Krzyszowski Zbigniew,” in Leksykon Teologii Fundamentalnej, 699.
} 


\section{THE ECCLESIOLOGICAL HERITAGE OF REV. MARIAN RUSECKI AND HIS STUDENTS}

Rev. Marian Rusecki also made sure the Lublin School grew in the field of ecclesiology. After his death, several of his students published a Treatise on the Church ${ }^{22}$ containing his most important ecclesiological texts. So far, three articles have been written summarizing his ecclesiology, ${ }^{23}$ which will be synthetically shown here.

He criticized intellectual apologetics for narrowing and deforming its subject matter (the institutional concept of the Church). Apologetic ecclesiology justified only some elements of the Church's structure (primacy, apostolate, their succession, the Magisterium of the Church), leaving aside all of its being, essence and the dynamics of its activity in the world. $\mathrm{He}$ drew attention to the necessity of an intrinsic binding of the Christological fact with the ecclesiological fact, which he regarded as two sides of one coin for fundamental theology. He analyzed the ecclesiology of the Second Vatican Council and, in accord with it, expanded the understanding of the Church, not simply limiting it to the Roman Catholic Church. The Church of Christ is embodied in the whole dynamic reality of Christian life, all local Churches, Christian Churches and ecclesial Communities (though to varying degrees, and according to the teachings of Vatican II, most fully present in the Roman Catholic Church). Ecclesiology is also somehow present in the elements of truth and sanctity found in non-Christian Religions.

Rev. Marian Rusecki distinguished the incarnation, salvation history, personalistic, semiotic (sign) and symbolic concepts of Ecclesiology (often this noun was replaced by the word "Church" wanting to protect its overlapping hieratics). He particularly developed its personalistic, salvation history and

\footnotetext{
${ }^{22}$ [Treatise on the Church], ed. Krzysztof Kaucha, Piotr Królikowski, Jacenty Mastej (Lublin: Wydawnictwo KUL, 2015).

${ }^{23}$ Krzysztof KaUCHA, “Czy Kościół jest wiarygodny? Dlaczego? Zawsze? Odpowiedź Rev. Mariana Ruseckiego," in Wiara pod lupa. Wspótczesne pytania o racjonalność wiary, ed. Rajmund Pietkiewicz (Wrocław: Towarzystwo Studiów Interdyscyplinarnych przy Papieskim Wydziale Teologicznym we Wrocławiu, 2014), 125-146; Zbigniew KrZYSZOwSKI, "Mysterium Ecclesiae w myśli naukowej Księdza Profesora Mariana Ruseckiego," in Scio Cui credidi. Księga pamiątkowa ku czci Księdza Profesora Mariana Ruseckiego w 65. rocznice urodzin, ed. Ireneusz S. Ledwoń, Krzysztof Kaucha, Zbigniew Krzyszowski, Jacenty Mastej, Andrzej Pietrzak (Lublin: Wydawnictwo KUL, 2007), 123-131; Krzysztof KaUCHA, "Wiarygodność Kościoła i jej uzasadnianie w twórczości naukowej M. Ruseckiego,” in Scio Cui credidi, 133-145.
} 
semiotic sides, pointing out that it is a mistake to ask: what is the Church? Rather, the question should be asked: who is the Church?

He constructed arguments for the Church's credibility not only on a solid methodological basis, but also thanks to the personal experience of the Church's credibility in the communist and post-communist times and during the pontificates of John Paul II and Benedict XVI. They can be reduced to four major points: 1. Christological (via christologica) where Jesus Christ himself is the most important and decisive argument for the credibility of Christianity and the Church and the source of all arguments provided by fundamental theology. The Church would never have arisen without His Person, giving it identity, Mystery, works and credibility; Rev. Rusecki regarded the Church as the historical-social-personal icon of Christ (the Christian iconicity of the Church); 2. The historical (via historica) is the Church's credibility recorded in history and should be justified with its help; the historical origins of the Church are sufficiently documented and related to the entire life of Jesus (the integral ecclesiogenesis concept); Rev. Rusecki proposed the theory of permanent ecclesiogenesis, proclaiming that the Church is a dynamic reality, not fully "finished" in its original form, but is constantly reborn and implemented through the message of God's Revelation (Tradition, Holy Bible, Magisterium), faith, testimony and liturgy; he also showed the credibility and durability of the Church, which were not destroyed but positively verified by numerous tests over time, e.g. persecutions or atheistic totalitarian ideologies; he believed that an important reason for the Church's credibility is keeping its identity despite external and internal opposition; 3. semantic (via signorum) - the traditional 4 signs were expanded by more, calling them signs of credibility correlated with the sign concepts of Divine Revelation and the Church (the term "sign" was used in a specific, religious-theological sense as a dual-element, mysterious empirical phenomenon containing in itself the supernatural reality, which the sign also points to; he devoted many scientific works to this concept); as signs of the Church's credibility, he elaborated on the sign of Peter, the Apostolic college, unity, holiness, universality, apostolicity, agapetology, praxeology, martyrology and culture-forming; he also studied the conditions for recognizing these signs and their motivational power; 4. axiological (via axiologica) arose in his work from the close bond between Jesus Christ, Christianity and the Church to the sphere of values, which led Rev. Rusecki to the conclusion that the demand for values and their credibility is a justification for the credibility of Jesus Christ as the embodiment of the most important values, 
such as truth, goodness, beauty, holiness, love, hope, etc.; in this way he sketched the axiological arguments (agapetological, bonative, calonistic, sanctity, veritative, hopeful); he also highlighted the personality-forming, historiographic and cultural forming role of Christian values.

Under his direction, over 40 doctoral dissertations were created, including in the field of ecclesiology, among others: Rev. Marek Żmudziński's "Awareness of the Primary Function of John Paul II in the Light of his Teachings" (1999), Rev. Tomasz Dereziński's "Embodiment of the Universal Church in the Particular Church in the Light of Post-Conciliar Literature" (2000), Rev. Waldemar Matusiak's "Theology of the Church's Presence in the World according to Marie-Dominique Chenu" (2001), Rev. Roman Słupek's "Collegiality of the Church according to Yves Congar" (2003), Rev. Dariusz Salamon's "The Church as the Transmitter of Revelation in Polish Post-Conciliar Theological Literature" (2005), Anna E. Bodnar's "Martyrdom as a sign of the Church's Credibility Based on the Example of the Ukrainian Greek Catholic Church in Ukraine in the Years 1944-1988" (2006), Rev. Mikołaj Węgrzyn's "Paschal Ecclesiogenesis in the Light of Polish-Language Post-Conciliar Literature" (2007), Piotr Królikowski's "Structural Credibility of the Church in the Ecclesiological Thoughts of Cardinal Avery Dulles" (2013).

Rev. Rusecki's ecclesiological literary works are developed at the Lublin school by his students: Rev. Dr. hab. Krzysztof Kaucha, Rev. Dr. hab. Jacenty Mastej, Fr. Dr. hab. Andrzej Pietrzak SVD and Rev. Dr. Paweł Borto.

Rev. Krzysztof Kaucha (born in 1968), since the beginning of his work at CUL (in 1997), mainly deals with ecclesiology. His literary work includes two monographs (a doctoral and a post-doctoral degree), ${ }^{24}$ about 50 research articles, about 50 lexicon and encyclopedic entries, 18 popular articles, 15 reviews and 16 reports. He is a co-editor of 9 collective works and multiauthor monographs. His research is based on the methodology of Rev. Rusecki in relation to fundamental theology as well as ecclesiology. He wrote two articles on meta-ecclesiology. ${ }^{25}$ Initially, his academic research

\footnotetext{
${ }^{24}$ Krzysztof KaUCHA, Mitość za mitość. Wiarygodność chrześcijaństwa wedtug Battisty Mondina (Lublin: RW KUL, 2000); Krzysztof KaUcha, Wiarygodność Kościoła w kontekście wyzwań wspótczesności europejskiej w świetle nauczania Jana Pawta II (Lublin: Wydawnictwo KUL, 2008).

${ }^{25}$ Krzysztof KAUCHA, "Eklezjologia fundamentalna. Zagadnienia metodologiczne," Roczniki Teologii Fundamentalnej i Religiologii 56, no 1 (2009): 29-46; Krzysztof KAUCHA, "Z metaeklezjologii," Roczniki Teologiczne 63, no 9 (2016): 65-80.
} 
dealt with the analysis of the dimensions and criteria of the Church's credibility, which he presented in his publications. ${ }^{26}$

In his post-doctoral thesis, he developed 15 arguments for the Church's credibility in the context of the challenges of European modernity in the light of the teachings of John Paul II, namely: the account of the Church's presence in European history, Europe building, reconciliation, anthropological and vocative, metaphysical, ethical, cultural formation, axiological, communion creating, praxeological, religious freedom, the Church's project regarding European integration, hopeful, martyrological and missionary. His dissertation also broadly presented the Pope's diagnosis of contemporary times. Then he continued via signorum Rev. Rusecki, identifying several dozen signs of the Church's credibility. ${ }^{27}$ In the last period, referring to the thoughts of Rev. Rusecki, he undertook research on the identity of the Church. ${ }^{28}$ Under his direction, two ecclesiological dissertations were created using the results of his research: Rev. Tomasz Kostecki's "Anthropological Credibility of the Church and its Justification in the Light of the Teachings of John Paul II" and Rev. Edwin Chukwudi Ezeokeke's "The Identity of the Catholic Church in Igboland, Nigeria."

Rev. Jacenty Mastej (born in 1967) has worked at CUL since 1998 and deals mainly with the methodology of fundamental theology, Christology, the theology of faith and Revelation, including defending the credibility of Christianity. He is the author of two monographs, several dozen scholarly articles and encyclopedic entries, and co-editor of several books. In 1999, under the direction of Rev. Rusecki, he wrote his doctoral dissertation entitled "The Personalistic Concept of the Act of the Christian Faith in the Light of Polish-Language Post-Conciliar Literature." ${ }^{29}$ In it, he began to study the

\footnotetext{
${ }^{26}$ Krzysztof KaUCHA, "Wiarygodność Kościoła,” in Kościót w czasach Jana Pawła II, ed. Marian Rusecki, Krzysztof Kaucha, Jacenty Mastej (Lublin: Wydawnictwo KUL, Wydawnictwo "Gaudium,” 2005), 335-359; Krzysztof KAUCHA, "Współczesne metody uzasadniania wiarygodności Kościoła," Roczniki Teologiczne 52, no 9 (2005): 77-96.

${ }^{27}$ Krzysztof KaUcha, “Znaki wiarygodności Kościoła,” Wrocławski Przegląd Teologiczny 19, no 1 (2011): 71-89; Krzysztof KAUCHA, "Znakowy charakter Kościoła w relacji do uzasadniania jego wiarygodności," in Apologia religii, ed. Piotr Moskal (Lublin: Wydawnictwo KUL, 2011), 249-273.

${ }^{28}$ Krzysztof KaUcha, “Tożsamość Kościoła w Polsce,” in Oblicza Kościoła katolickiego w Polsce. 1050 rocznica Chrztu, ed. Jacenty Mastej, Krzysztof Kaucha, Paweł Borto (Lublin: Wydawnictwo KUL, 2016), 275-306; Krzysztof KAUCHA, "The Identity of Local and Particular Catholic Churches. Methodological Outline,” Roczniki Teologiczne 64, no 9 (2017): 45-58.

${ }^{29}$ Jacenty MASTEJ, Od objawienia do wiary. Personalistyczna koncepcja aktu wiary chrześcijańskiej (Lublin: Wydawnictwo KUL, 2001).
} 
Church's permanent ecclesiogenesis and its realization, in which he referred to the thoughts of Rev. Rusecki. In his habilitation thesis,${ }^{30}$ he widely justified paschal ecclesiogenesis. The issue of ecclesiogenesis is the subject of several of his research articles. ${ }^{31}$

Rev. Andrzej Pietrzak (born in 1958) was employed at the IFT in 2005. He worked as a missionary in the slums in São Paulo and the poor regions of Brazil (1980-90), which shaped his academic interests mainly including the Church in Latin America, the theology of poverty and missiology. In 2001, he obtained a doctorate in fundamental theology at the Catholic University of Lublin on the basis of the dissertation "The Option for the Poor as a Sign of the Church's Credibility in the Light of the Final Documents of the Latin American Episcopate's General Conferences in Rio de Janerio, Medellin, Puebla and Santo Domingo,"32 written under the direction of Rev. Rusecki. In the years 2004-05, he completed studies in the field of missiology at the Gregorian, defending his licentiate in missiology. He obtained his habilitation in 2014 on the basis of his achievements and dissertation. ${ }^{33} \mathrm{He}$ has published 4 books (including 2 in Portuguese), 31 research articles (in Polish, English, Portuguese and Spanish) ${ }^{34} 10$ popular academic articles and edited 3 books.

Rev. Paweł Borto (born in 1969) has been an IFT employee since 2009. In 1996, at the Pontifical Lateran University in Rome, he obtained a master's degree in fundamental theology based on his work, "La dimensione pneumatica del progresso della Tradizione. Le implicazioni di Dei Verbum 8

\footnotetext{
${ }^{30}$ Jacenty MASTEJ, Staurologiczno-rezurekcyjna wiarygodność chrześcijaństwa (Lublin: Wydawnictwo KUL, 2009, 2014²).

${ }^{31}$ Jacenty MASTEJ, "Permanentna eklezjogeneza," in Kościót w czasach Jana Pawła II, ed. Marian Rusecki, Krzysztof Kaucha, Jacenty Mastej (Lublin: Wydawnictwo KUL, Wydawnictwo „Gaudium,” 2005), 113-125; Jacenty MASTEJ, "Miłosierdzie w funkcji eklezjotwórczej," Roczniki Teologiczne 63, no 9 (2016): 21-42; Jacenty MASTEJ, "Eklezjotwórcza funkcja wiary," Studia Leopoliensia 6 (2013): 181-189; Jacenty MASTEJ, "In virtute Spiritus Sancti. Eklezjogenetyczny dar Ducha Świętego," in W mocy Ducha Świętego: księga pamiątkowa dla Jego Ekscelencji Księdza Biskupa Edwarda Białogłowskiego z okazji XXV rocznicy święceń biskupich, ed. Piotr Mierzwa, Marcin Nabożny (Rzeszów, 2013), 163-174.

${ }^{32}$ Andrzej PIETRZAK, Opcja na rzecz ubogich znakiem wiarygodności Kościoła (Pieniężno: Referat Misyjny Seminarium Duchownego Księży Werbistów, 2002).

${ }^{33}$ Andrzej PIETRZAK, Modele ewangelizacji kultur i inkulturacji wiary w teologii latynoamerykańskiej (Lublin: Wydawnictwo KUL, 2013).

${ }^{34}$ Including: Andrzej PieTRZAK, "Metoda via ascendens i jej znaczenie w badaniach eklezjologicznych na przykładzie Ameryki Łacińskiej," Roczniki Teologiczne 63, no 9 (2016): 95-110; Andrzej PIETRZAK, "Ubodzy w nauczaniu Jana Pawła II w Ameryce Łacińskiej," in Jan Pawet II w Ameryce Środkowej, ed. Tomasz Szyszka (Warsaw: Instytut Papieża Jana Pawła II, 2017), 61-70.
} 
alla luce del documento della CTI su L'interpretazione dei dogma." ${ }^{35}$ In 2003, he defended his doctorate, "Tradition and Revelation in the Theology of Yves Congar and Henri de Lubac," ${ }^{36}$ written under the direction of Rev. Rusecki. He is the author of over 20 research articles. Examining the problems of Tradition in the Church, he continues the achievements of Rev. R. Łukaszyk. In his works, he uses the ecclesiology of contemporary masters: Y. Congar, H. de Lubac and J. Ratzinger. ${ }^{37} \mathrm{He}$ analyzed the Marian dimension of ecclesiology ${ }^{38}$ the meaning of the term "faith in the Church" 39 and the concepts of sensus fidei. ${ }^{40}$

Rev. Rusecki's students refer to the analyzes on the contemporary condition of the Church that he initiated. ${ }^{41}$ They continue these studies and their results have been published in several collective works. ${ }^{42}$ Recently, they published a research monograph, the result of a broad project carried out jointly with theologians from other centers, entitled Fundamental Theology in the Works of Joseph Ratzinger. ${ }^{43}$ Also very recently, they published a research monograph entitled Methodology of Fundamental Theology. This book reminds Rev. Rusecki's contribution in this field. In this monograph Rev. Mastej published the article dedicated to methodology of fundamental

\footnotetext{
${ }^{35}$ Zbigniew KrZYszowsKI, "Borto Paweł,” in Leksykon Teologii Fundamentalnej, 156.

${ }^{36}$ Paweł Borto, Tradycja a Objawienie w teologii Yves'a Congara i Henri de Lubaca (Kielce, 2007).

${ }^{37}$ Paweł Borto, "Yves'a Congara spojrzenie na Kościół jako podmiot Tradycji," Kieleckie Studia Teologiczne 2 (2003), 153-176; Paweł BoRTo, "Wiarygodność Kościoła według Josepha Ratzingera," Roczniki Teologiczne 64, no 9 (2017): 73-86.

${ }^{38}$ Paweł BorTo, "Profil Maryjny Kościoła. Eklezjologiczne implikacje nauczania papieży," Studia Theologica Varsaviensia 50 (2012): 221-243.

${ }^{39}$ Paweł BorTo, "Formuła «Wierzę w Kościół» w symbolu wiary i jej teologiczne znaczenie," Studia Teologiczno-Historyczne Śląska Opolskiego 33 (2013): 209-227.

${ }^{40}$ Paweł BORTO, "Teoria i praktyka uwzględniania sensus fidelium przez Magisterium w czasach nowożytnych,” in Wiara-wiarygodność, ed. Damian Wąsek (Kraków, 2014), 115-141; Paweł BORTO, "Sensus fidei i jego znaczenie w praktyce Kościoła," in Poktadamy nadzieję w Kościele, ed. Dawid Mielnik (Lublin, 2016), 82-99.

${ }^{41}$ Marian RUSECKI, Wiarygodność Kościoła wobec przemian w Polsce. Quo vadis Ecclesia Polonorum? ed. Marian Rusecki (Pelplin-Lublin, 1994); Marian RUSECKI, Problemy wspótczesnego Kościoła, ed. Marian Rusecki (Lublin: RW KUL, 1996).

${ }^{42}$ Kościót w czasach Jana Pawta II, ed. Marian Rusecki, Krzysztof Kaucha, Jacenty Mastej (Lublin: Wydawnictwo KUL, Wydawnictwo „Gaudium,” 2005); Rok Wiary—rok odnowy, ed. Krzysztof Kaucha, Andrzej Pietrzak, Wojciech Rebeta (Lublin: Wydawnictwo KUL, 2013); Oblicza Kościota katolickiego w Polsce. 1050 rocznica Chrztu, ed. Jacenty Mastej, Krzysztof Kaucha, Paweł Borto (Lublin: Wydawnictwo KUL, 2016).

${ }^{43}$ [Fundamental Theology in Joseph Ratzinger's Works], ed. Krzysztof Kaucha, Jacenty Mastej (Lublin: Wydawnictwo KUL, 2017).
} 
Christology and Rev. Kaucha-the article dedicated to methodology of fundamental ecclesiology. ${ }^{44}$

Academic research in the field of ecclesiology, as a part of fundamental theology, has been conducted at CUL since the beginning of its existence. This is understandable, since its close relationship with the Church is inscribed in the identity of the Catholic university and all disciplines of Catholic theology. These studies showed the changes analogous to the changes in European Catholic ecclesiology over the last century. At first, it was a dogmatic-apologetic and polemical ecclesiology against Russian Orthodoxy (Rev. Kremer), then Rev. Kopeć and Rev. Nagy taught traditional theology in the spirit of intellectual apologetics. Later on, Rev. Nagy transformed it into post-conciliar ecclesiology with an increasingly distinctive theological and ecumenical profile, which was also done by Rev. Łukaszyk. Rev. Rusecki contributed the most by synchronizing ecclesiology and Christology (in Rev. Kopeć and Rev. Nagy, these two were independent), and broadened the arguments for the Church's credibility. His achievements are now being developed by his students.

\section{BIBLIOGRAPHY}

Kaucha, Krzysztof. "Czy Kościół jest wiarygodny? Dlaczego? Zawsze? Odpowiedź Rev. Mariana Ruseckiego" [Is the Church Credible? Why? Always? Rev. Marian Rusecki Gives Answers]. In Wiara pod lupą. Wspótczesne pytania o racjonalność wiary [Faith Under the Microscope. Contemporary Questions about the Rationality of the Faith], edited by Rajmund Pietkiewicz, 125-146. Wrocław: Towarzystwo Studiów Interdyscyplinarnych przy Papieskim Wydziale Teologicznym we Wrocławiu, 2014.

KAUCHA, Krzysztof. "Wiarygodność i wiara w ujęciu lubelskiej szkoły teologii fundamentalnej" [Credibility and Faith according to the Lublin School of Fundamental Theology]. In Wiarawiarygodność [Faith—Credibility], edited by Damian Wąsek, 49-85. Kraków: Wydawnictwo Naukowe UPJPII w Krakowie, 2014.

KAUCHA, Krzysztof. "Wiarygodność Kościoła i jej uzasadnianie w twórczości naukowej M. Ruseckiego" [The Church's Credibility and its Justifying in the Scholarly Works of M. Rusecki]. In Scio Cui credidi. Księga pamiątkowa ku czci Księdza Profesora Mariana Ruseckiego w 65. rocznice urodzin [Scio Cui credidi. Commemorative Book Dedicated in Honor of Rev.

\footnotetext{
${ }^{44}$ Marian Rusecki, Jacenty MASTEJ, Krzysztof KaUCHA, Methodology of fundamental theology, ed. Jacenty Mastej, Krzysztof Kaucha (Lublin: TN KUL, 2019).
} 
Professor Marian Rusecki on his $65^{\text {th }}$ Birthday], edited by Ireneusz S. Ledwoń, Krzysztof Kaucha, Zbigniew Krzyszowski, Jacenty Mastej, Andrzej Pietrzak, 133-145. Lublin: Wydawnictwo KUL, 2007.

KumoreK, Adam. Wiarygodność chrześcijaństwa w pismach kardynata Stanisława Nagyego SCJ. [The Credibility of Christianity in the Writings of Cardinal Stanisław Nagy SCJ]. Warsaw, 2013 (doctoral dissertation).

KrZYszowski, Zbigniew. "Mysterium Ecclesiae w myśli naukowej Księdza Profesora Mariana Ruseckiego" [Mysterium Ecclesiae in the Scholarly Thoughts of Rev. Professor Marian Rusecki]. In Scio Cui credidi. Księga pamiatkowa ku czci Księdza Profesora Mariana Ruseckiego w 65. rocznice urodzin [Scio Cui credidi. Commemorative Book Dedicated in Honor of Rev. Professor Marian Rusecki on his $65^{\text {th }}$ Birthday], edited by Ireneusz S. Ledwoń, Krzysztof Kaucha, Zbigniew Krzyszowski, Jacenty Mastej, Andrzej Pietrzak, 123-131. Lublin: Wydawnictwo KUL, 2007.

Leksykon Teologii Fundamentalnej [Lexicon of Fundamental Theology], edited by Marian Rusecki, Krzysztof Kaucha, Ireneusz S. Ledwoń, Jacenty Mastej. Lublin-Kraków: Wydawnictwo M, 2002.

ŁUKASZYK, Romuald. "Pięćdziesięciolecie teologii fundamentalnej na KUL (1919-1968)" [Fifty Years of Fundamental Theology at CUL (1919-1968)]. Roczniki Teologiczno-Kanoniczne 15, no 2 (1968): 5-53.

NAGY, Stanisław. "Sekcja Teologii Fundamentalnej” [Section of Fundamental Theology]. In Księga pamiątkowa w 75-lecie Katolickiego Uniwersytetu Lubelskiego. Wkład w kulturę polska w latach 1968-1993 [Jubilee Book on the $75^{\text {th }}$ Year Anniversary of the Catholic University of Lublin. Contribution to Polish Culture in the Period of 1968-1993], edited by Marian Rusecki, 188-197. Lublin: RW KUL, 1994.

Roczniki Teologiczne 31, no 2 (1984).

Roczniki Teologiczne 43, no 2 (1996).

RUSECKI, Marian. Traktat o Kościele [Treatise on the Church], edited by Krzysztof Kaucha, Piotr Królikowski, Jacenty Mastej. Lublin: Wydawnictwo KUL, 2015.

RUSECKI, Marian. Wiarygodność chrześcijaństwa, vol. 1: Z teorii teologii fundamentalnej [Credibility of Christianity, vol. 1: From the Theory of Fundamental Theology]. Lublin: TN KUL, 1974.

RUSECKI, Marian, Jacenty Mastej, Krzysztof Kaucha. Methodology of fundamental theology, ed. Jacenty Mastej, Krzysztof Kaucha. Lublin: TN KUL, 2019.

Translated by Jan Kobytecki

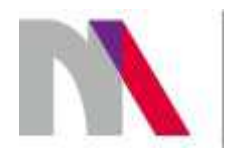

The preparation of the English version of Roczniki Teologiczne (Annals of Theology) and its publication in electronic databases was financed under contract no. 836/P-DUN/2018 from the resources of the Minister of Science and Higher Education for the popularization of science. 